\title{
Managing agricultural intensification: The role of international research
}

\author{
William D. Dar ${ }^{\mathrm{a}}$, Stephen J. Twomlow ${ }^{\mathrm{b}, *}$ \\ ${ }^{a}$ International Crops Research Institute for the Semi-Arid Tropics (ICRISAT), Patancheru 502 324, Andhra Pradesh, India \\ ${ }^{\mathrm{b}}$ Agro-ecosystem Development, International Crops Research Institute for the Semi-Arid Tropics (ICRISAT), P.O. Box 776, Bulawayo, Zimbabwe
}

Received 15 December 2004; accepted 5 April 2006

\begin{abstract}
Over the next $20-25 \mathrm{yr}$, global food demand is expected to increase by around $50 \%$, largely due to demand in developing countries. The challenge is to increase production without damaging the natural resource base. Various technologies for integrated natural resource management (INRM) have been developed, but adoption has been poor, for various reasons-technical, socio-economic, and institutional.

To date a great deal of past work has focused at the plot and farm level, with little farmer involvement in developing the research agenda. Work needs to be extrapolated to more sites, with greater farmer involvement in the research process, in order to answer the key question: 'Under what conditions will rural households be encouraged to reinvest in their agroecosystems?'

Encouraging such investment involves several challenges: improving returns from such investments; creating market access for smallholder farmers; improving research-extension-farmer linkages; developing enabling policies on soil, water and biodiversity; integration of livestock-wildlife-crop systems; development of drought mitigation strategies; capacity building; better information flow; and a clearer gender perspective in research and training.

A large body of successful INRM research is available from many countries in the West and in Latin America. Unfortunately much of this work is reaching sub-Saharan Africa only now, and its appropriateness to the needs of the African smallholder farmer requires verification. This paper shares some of the experiences of the Consultative Group on International Agricultural Research (CGIAR), International Agricultural Research Centers (IARCs) in Africa, particularly the International Crops Research Institute for the Semi-Arid Tropics (ICRISAT). Reference is made to some specific technologies and some limited successes with small-scale farmers in Africa. (C) 2006 Elsevier Ltd. All rights reserved.
\end{abstract}

Keywords: Integrated natural resource management; Agricultural development; Sub-Saharan Africa; Soil fertility; Participatory research

\section{Introduction}

'For the first time, we may have the technical capacity to free mankind from the scourge of hunger... within a decade no man, no woman, or child will go to bed hungry' (Henry Kissinger, United Nations World Food Conference 1974).

When Henry Kissinger made this statement the first Green Revolution was at its peak, and there was a great deal of optimism over mankind's technical capabilities to eradicate hunger. Today, we find that some of this early optimism was justified, some was not. Over the last three decades world food production has grown faster than population. Per capita food production today is about

\footnotetext{
${ }^{*}$ Corresponding author. Tel.: + 263838323 ; fax: +263838253

E-mail address: s.twomlow@cgiar.org (S.J. Twomlow).
}

$18 \%$ higher than it was $30 \mathrm{yr}$ ago. But despite this, an estimated 1.3 billion people go to bed hungry every night. Also, there are huge inequalities in food availability in both developed and developing countries (FAO, 1996, 1999; USDA, 2000; Ryan and Spencer, 2001; Johnson et al., 2003; Benson, 2004). Mankind has been able in the recent past to reduce levels of undernutrition and meet the growing demand for food in much of the developing world, with the exception of sub-Saharan Africa (Fig. 1). A bigger challenge is how to maintain long-term sustainability, given the current trends of degradation in the natural resource base.

Over the next 20-25 yr, global food demand is expected to increase by around $50 \%$. About $80 \%$ of the increased demand is expected to come from developing countries, particularly countries in sub-Saharan Africa where 


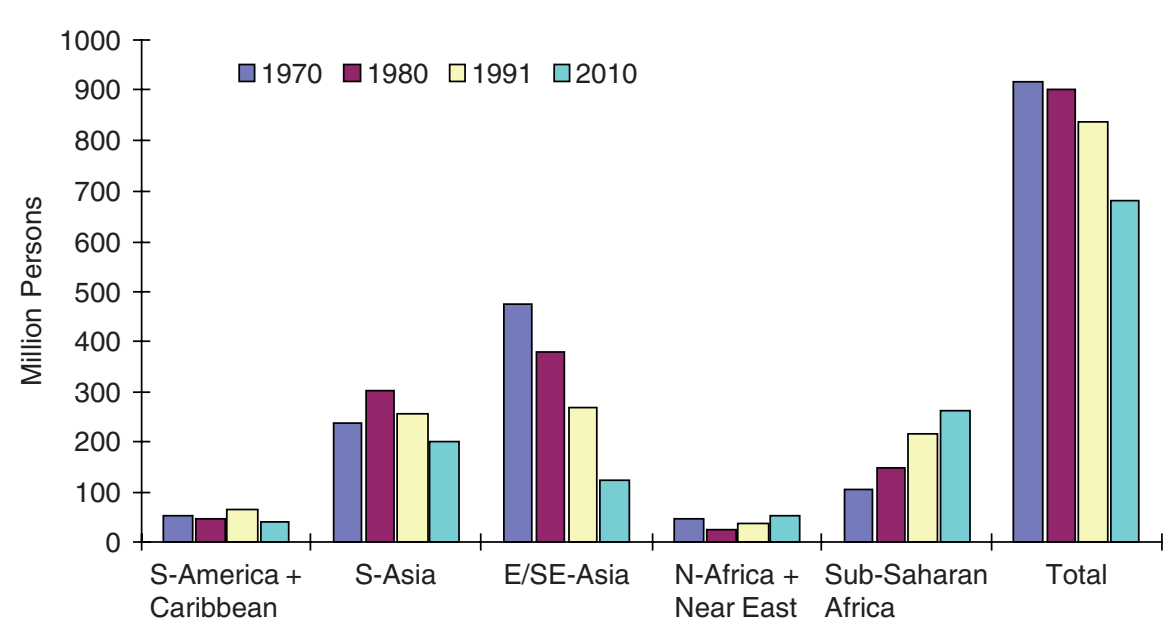

Fig. 1. Trends in undernutrition in different regions of the world (FAO, 1999).

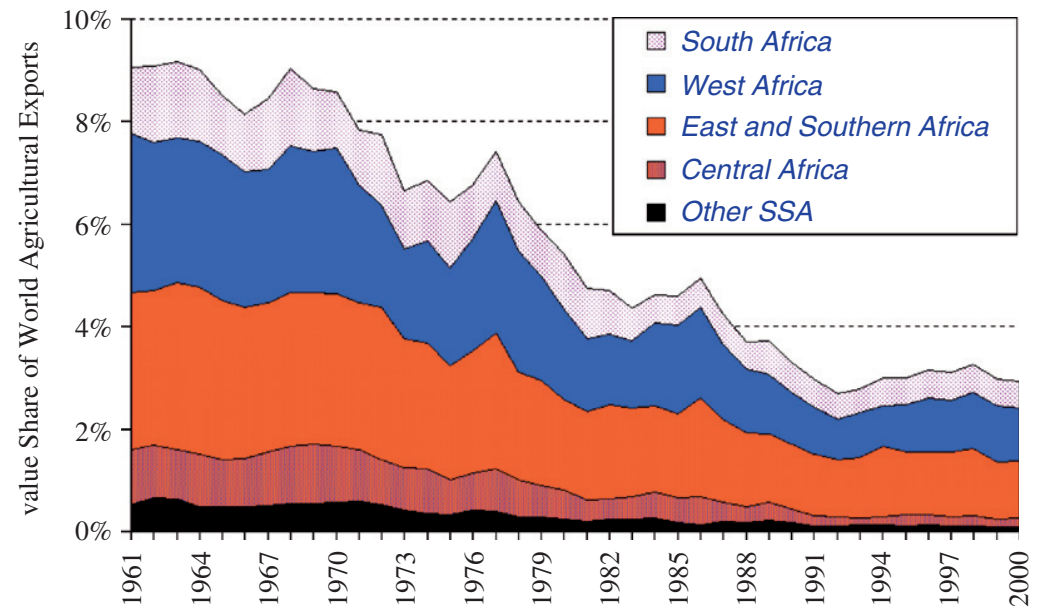

Fig. 2. The decline in Africa's share of global agricultural exports, adapted from Johnson et al. (2003).

nutritional deficits are still increasing (Fig. 1). Unfortunately, as farmers seek to increase production, the problem of inappropriate management practices arises. In Africa the problems of sustainability of resource use are particularly serious: Africa lags behind the rest of the world, with an overall net decline in agricultural productivity (Johnson et al., 2003). Fig. 2 highlights the decline in Africa's share of global agricultural exports. Simultaneously, the percentage of people depending primarily on natural resourcessoil, rangeland, forestry products, fish-for their livelihoods, is higher in Africa than anywhere else. It is our duty to future generations to find ways to enhance productivity and production, without drawing down our stock of natural capital. Land, water, forests and rangeland, the environment as a whole and the farming systems within it, must be conserved and protected, as sustainable agricultural growth is the key to Africa's future (Fischer and Heilig, 1998; Ryan and Spencer, 2001). Stagnant agriculture means economic stagnation for most Africans (Box 1, adapted from Johnson et al., 2003).

\section{Agricultural growth and the importance of integrated natural resource management (INRM)}

The agroecosystems of semi-arid sub-Saharan Africa have developed in response to the needs of both rural and urban populations. The traditional production systems of rural households are thought to be generally sustainable under conditions of low population pressure and lack of market integration, with system productivity geared towards subsistence (Barrow, 1988; Reij et al., 1996; Barbier, 1998). These systems remain in sustainable equilibrium until change, such as population growth or external economic pressures, occurs at a rate faster than can be accommodated without resource degradation (Fischer and Heilig, 1998). These internal and external forces can bring about an intensification of agriculture, or an extensification into marginal lands, where the risk of crop failure, environmental degradation and loss of biodiversity increases due to inappropriate management practices that can exhaust the soils of nutrients and organic 
Box 1

Africa's Agricultural Challenge and Potential.

The Challenge:

- Rapid population growth $(2.5 \%$ per year)

- Per capita GDP is stagnant, even negative in many countries

- Negative growth in per capita food production

- $80 \%$ of Africans live on less than 2 US dollars per day, and about half live on less than one US dollar per day

- Over 30 million children are seriously malnourished

- Widespread conflicts (14 countries in 1999 alone, generating 18 million refugees)

Agricultural Growth is the Key:

Agriculture accounts for:

- $30 \%$ of total Gross domestic product

- $40 \%$ of total export earnings

- $70 \%$ of the labor force

- $80 \%$ of the population depend on agriculture for their livelihoods

\section{The Potential:}

- Africa has abundant natural resources (cp. India: $0.08 \%$ land area but feeds twice as many people)

- A growing rural labor force despite HIV/AIDS

- Growing domestic markets with rapid urbanization, new export opportunities and prospects for more inter-regional trade

- Current low yields are an opportunity

- Most farmers are small but efficient, offering 'win-win' opportunities for growth and poverty alleviation.

matter and leave them vulnerable to erosion (Gregory and Ingram, 2000). Many of the changes taking place reflect higher community expectations and better opportunities as a result of integration of urban and rural livelihoods, physical (roads) and social (schools) infrastructure development, and general economic growth. The new expectations and opportunities compete for available resources for investment choices, often at the expense of investment in natural resource management; indeed, they may encourage overexploitation of natural resources.

It is now widely recognized at policy level that resource management is the key to human well being; and that land and water resources are the most valuable assets in the war against poverty in Africa (Ryan and Spencer, 2001; Freeman et al., 2002). This point is made clear by The New Partnerships for Africa's Development (NEPAD) "Comprehensive Africa Agricultural Development Program", which states that (one of the four) ... fundamental mutually reinforcing pillars on which to base the immediate improvement of Africa's agriculture, food security and trade balance, is extending the area under sustainable land management and reliable water control systems (NEPAD, 2002).

INRM is a key research theme under NEPAD. But past experience has shown that INRM technologies are hard to develop; and even harder to successfully disseminate
(Barrett et al., 2002; Campbell and Sayer, 2003; CIMMYT, 2003; Douthwaite et al., 2003; Harwood and Kassam, 2003; Perez and Tschinkel, 2003; Pound et al., 2003; Shiferaw and Freeman, 2003; Agricultural Systems vol. 78). Researchers face a range of challenges. First, climatic variability leads to unreliability in the soil-moisture available for plant growth. Second, most soils in subSaharan Africa are of inherently low fertility (Sanchez, 2002). Cropping practices such as continuous cereal cultivation and reduced fallows, coupled with very low use of organic or inorganic fertilizer, lead to a high rate of nutrient depletion. Third, most farmers operate at subsistence level. They cannot, or will not, invest in the development and sustainable management of land and water resources. Therefore, even where suitable technologies are available, adoption is low.

The problem is that incentives to pursue environmentally sustainable practices are commonly lower than incentives to simply extract natural resources. The value of an additional dollar of output today is worth far more to most small-scale African farmers than the value of much larger production gains in the distant future. Many developed countries have resolved this problem by paying farmers either to take land out of production or to adopt more sustainable practices. Unfortunately, few developing 


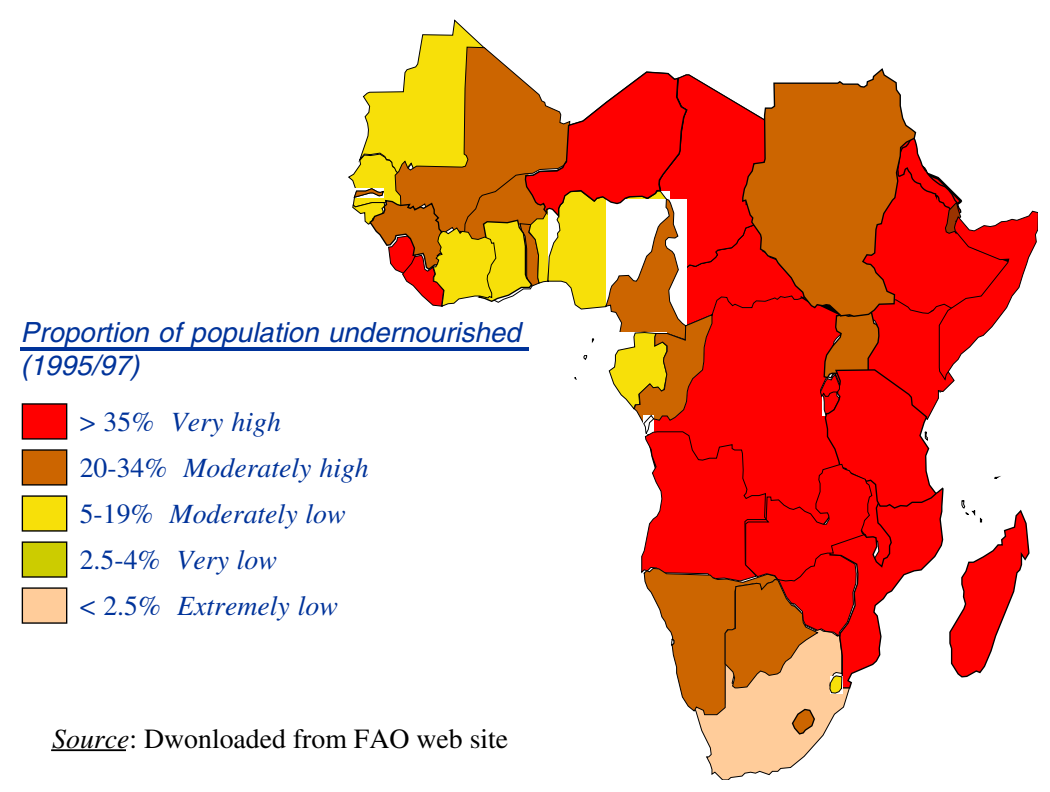

Fig. 3. The widespread prevalence of hunger in Africa.

countries have the capacity to make similar investments. The majority of Africa's poorest and most food-insecure households live in semi-arid areas (Ryan and Spencer, 2001; Fig. 3). To survive in a harsh and variable environment, they pursue a range of livelihood strategies. Different households pursue different development paths. But almost all seek to diversify their income sources and investment strategies as a means to reduce risk and, if possible, respond to rapidly changing market conditions (Freeman et al., 2002).

Many African farmers face food production deficits virtually every year due to the poor agricultural potential of their natural resource base, undeveloped markets and poor infrastructure (Benson, 2004). Commercial agriculture may be too ambitious for this group in the medium term, without a massive influx of development capital - we need a subset of technologies that specifically target food security in the poorest households and provide them diversified options for generating income through access to alternative crops, new varieties with marketing potential, and through organizational and institutional development. Correspondingly, technology delivery can be linked with the development of inter-rural markets to move food from surplus to deficit areas; and also linked with the commercialisation of production for sale to urban or export markets. In areas with better farming conditions and market access, research programs should focus on market-oriented production and value addition; but technologies must offer competitive returns to labor and capital compared with alternative income-earning opportunities.

The lessons learned to date are that technologies need to be matched not only with the crop or livestock enterprise and the biophysical environment, but also with the market and investment environment, that includes functional seed systems supported by regionalized breeding programs (Ryan and Spencer, 2001; Freeman et al., 2002). In East, West and Southern Africa, the International Agricultural Research Centers of the Consultative Group on International Agricultural Research (CGIAR), in partnership with National Agricultural Research and Extension systems, have been promoting awareness of rural seed distribution systems to ensure that farmers have access to crop varieties that will improve household subsistence, and processors have access to varieties that meet market needs. Part of this work includes understanding the paradigm shifts required by public and private sector research and extension to support farmer-processor-market linkages, especially contract farming and obligations of each party involved. The lessons learned over the last $5 \mathrm{yr}$ are that plant breeders and natural resource management scientists must integrate their work with the change agents (both public sector and private) so that flexible cropping systems can be developed using participatory approaches, with target groups, that can respond to rapid changes in market opportunities. In the longer term carefully prioritized biotechnology work, that acknowledges consumer concerns, will underpin these activities.

With this integrated approach in mind the International Crops Research Institute for the Semi-Arid Tropics (ICRISAT) has expanded the INRM paradigm to acknowledge the role crops and genetic improvement can play in enabling African agriculture to achieve its potential. There is a growing acceptance of the expanded version of this term to include both genetic and nongenetic solutions-Integrated Genetic and Natural Resource Management (IGNRM). Fig. 4 shows that the largest productivity gains in the semi-arid tropics can come from combining new varieties with improved crop management (Heinrich, 2004). 


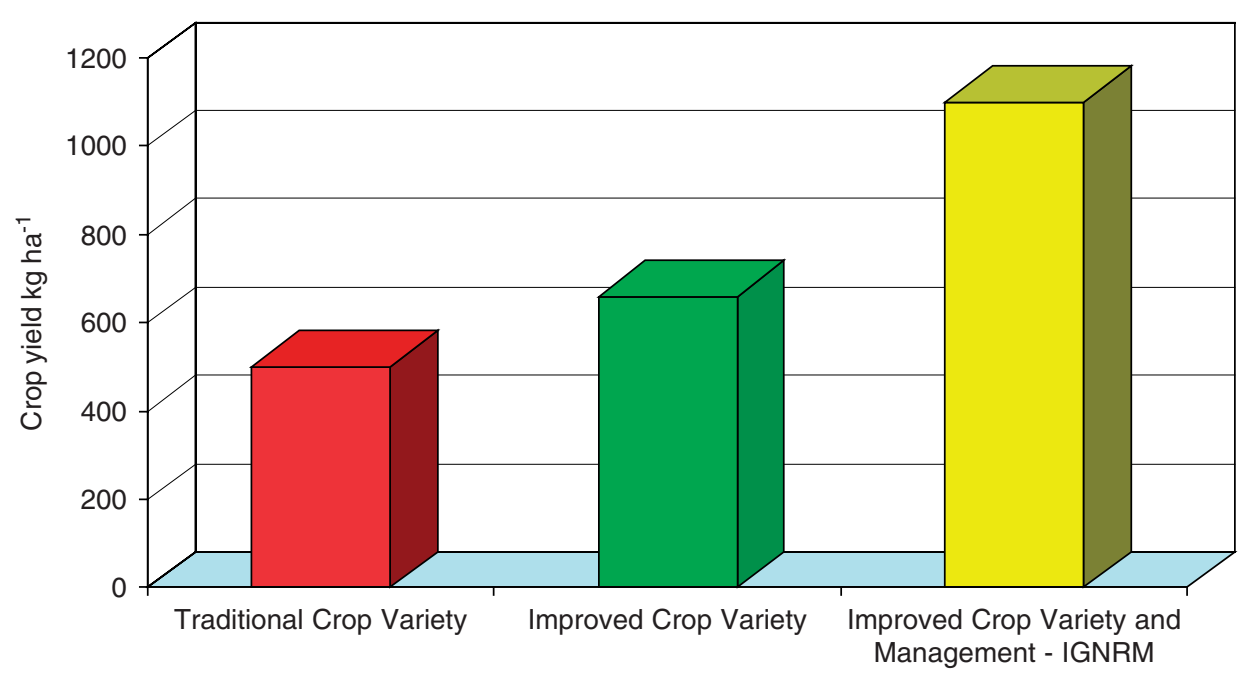

Fig. 4. Contribution of different technology components on sorghum yield, as observed in on-farm trials in Zimbabwe. Source: Heinrich (2004).

\section{ICRISAT's contribution}

ICRISAT has worked on various areas. Soil conservation methods have been developed to conserve water and reduce runoff. Land preparation methods have reduced water-logging problems and made cultivation possible on hard-to-work clay soils (Cogle et al., 1997). There has been good progress in weed control, using a combination of genetic improvement and low-input control methods based on improved agronomic practices, rather than expensive herbicides (Hess et al., 1996). For example, an ongoing USAID-funded project on Striga involves ICRISAT, Purdue University, and several national programs in southern Africa. In east Africa integrated pest management research has led to a series of successes in the management of pigeon pea insect pests (Minja et al., 1999). Technologies developed by ICRISAT in India, have been modified - with scientists working jointly with farmers and extension specialists - to suit conditions in various environments in Africa (Chauhan et al., 1997; Nakano et al., 2002). In partnership with the World AgroForestry Center and other agencies, we have promoted the integration of productive tree and shrub species into the ecosystem to improve supplies of fodder and fuel, and also improve soil conservation and reduce erosion (Snapp et al., 1998).

ICRISATs' research on watersheds has attracted considerable interest from research institutions, and substantial funding from one of India's largest private trusts, the Tata Foundation. We have demonstrated at a series of pilot locations, how the community can organize itself to manage water resources on a collective basis. In these pilot communities we have provided not only the scientific basis for water management and harvesting, but also identified specific income-generating opportunities (nontraditional cash crops), promoted biological control methods against insect pests, and demonstrably reduced erosion and land degradation. These schemes are now being scaled out to larger areas, in partnership with NGOs and national research and extension agencies (Wani et al., 2003). Many of the lessons learned in Asia are in the process of being transferred to East Africa under the auspices of the Soil Water Management Network (SWMnet) for Eastern Africa.

ICRISAT has worked in sub-Saharan Africa for over 2 decades, in collaboration with a range of partners. These include national research organizations, extension agencies, universities, nongovernmental organizations, farmer organizations, and the private sector. Natural resource management has always been a key element of the Institute's research agenda-taking into account soil, water, nutrient balance and economic aspects, in a farming systems perspective, considering crops as well as livestock.

After drought, the single biggest constraint to smallholder farming in Africa is poor soil fertility. Accordingly, ICRISAT has invested a great deal of resources in soil fertility management and appropriate on-farm methodologies (Rusike et al., 2005), such as the mother-baby trial approach, used to test 'best-bet' legume-based soil fertility management technologies in Malawi since 1997 (Fig. 5). Three seasons' results showed that the legume intensified 'best-bet' systems, detailed in Table 1, performed as expected, increasing yields from as little as $0 \mathrm{~kg} \mathrm{ha}^{-1}$ in the $1997 / 1998$ season, to above $3000 \mathrm{~kg} \mathrm{ha}^{-1}$ in the $1999 /$ 2000 season when compared to unfertilized maize. Yet, farmers still expressed concerns about the marginal loss of maize production and the labor implications. They weighed the benefits of weed suppression and potential cash earning, against input costs, problems of seed and fertilizer access, and problems of grain market delivery. The mother-baby approach facilitated farmer and researcher evaluation of technologies in terms of both agronomic and economic performance, and allowed farmers to see for themselves the performance of treatments under different management conditions (see Table 1, Twomlow et al., 2004). 


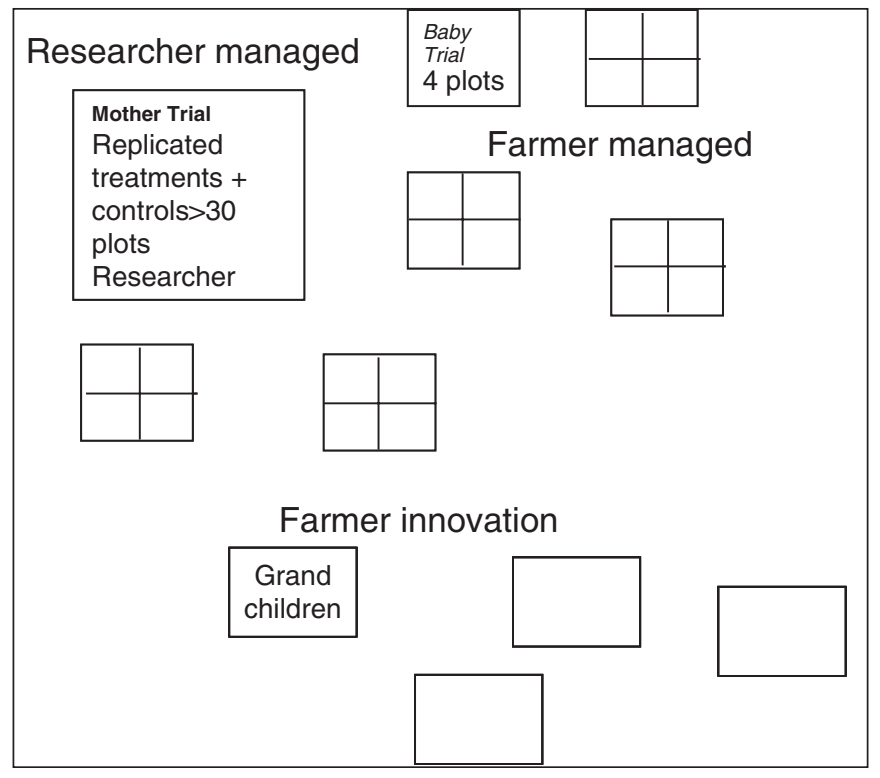

Fig. 5. Typical layout for mother-baby trials used by ICRISAT in Africa. Source: Rusike et al. (2005).

Table 1

Ranking of acceptability of technology options tested in Malawi using the Mother-Baby Approach

\begin{tabular}{llll}
\hline Best bet option & $\begin{array}{l}\text { Agronomic }^{\mathrm{a}} \\
\text { acceptability }\end{array}$ & $\begin{array}{l}\text { Economic }^{\mathrm{b}} \\
\text { acceptability }\end{array}$ & $\begin{array}{l}\text { Farmer }^{\mathrm{c}} \\
\text { acceptability }\end{array}$ \\
\hline $\begin{array}{l}\text { Unfertilized maize } \\
\text { Maize + area specific }\end{array}$ & 5 & 6 & 5 \\
fertilizer & 2 & 4 & 7 \\
$\begin{array}{l}\text { Maize + pigeonpea } \\
\text { Maize + pigeonpea + area }\end{array}$ & 1 & 2 & 2 \\
specific fertilizer & & 3 & 6 \\
$\begin{array}{l}\text { Groundnut + pigeon pea } \\
\text { Maize + Tephrosia }\end{array}$ & 6 & 5 & \\
Mucuna-maize rotation & 7 & 7 & 3 \\
\hline
\end{tabular}

Source: Twomlow et al., 2004.

$1=$ highest, $7=$ lowest ranking.

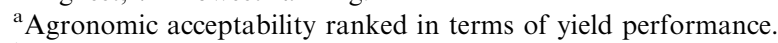

${ }^{b}$ Economic acceptability ranked in terms of marginal rates of return analyses.

${ }^{\mathrm{c}}$ Farmer acceptability based on seasonal matrix ranking exercises.

In addition to working with legumes ICRISAT has successfully promoted the use of manure-fertilizer combinations, even in areas where farmers wrongly perceived them as alternative (rather than complementary) inputs (Dimes et al., 2003). On-farm experimentation with farmers in drier regions of Zimbabwe has confirmed the profitability of low rates of $\mathrm{N}$ fertilizer, either alone or in combination with manure. Animal manure can be used as a replacement for basal fertilizer, at rates of application in line with the amounts typically available on smallholder farms. The response to manure can be increased when a small top dressing of $\mathrm{N}$ (half a bag of $\mathrm{AN}$ or $9 \mathrm{~kg} \mathrm{~N} \mathrm{ha}^{-1}$ ) is

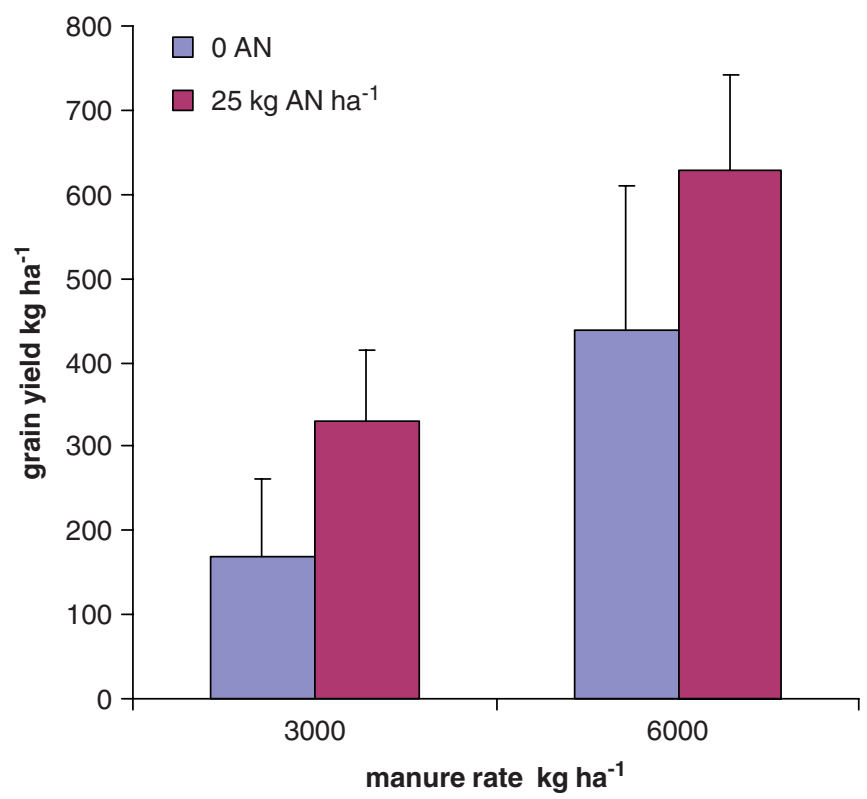

Fig. 6. Maize yield response to low and high rates $\left(3 \mathrm{t}, 6 \mathrm{tha}^{-1}\right)$ of manure, alone and in combination with a low dose of ammonium nitrate. Source: Dimes et al. (2003).

applied at the 5-6 leaf stage of cereal crops. This benefit can be seen even in seasons of severe moisture stress, as occurred in 2001/2002 (Fig. 6).

When household resources to invest in fertilizer and labor (for weeding) are limited, the important question for a farmer is which of these alternative investments offers the best return. Many researchers, extension agents and farmers in sub-Saharan Africa lack the information needed to answer this question for a given situation (Ryan and Spencer, 2001). Research has shown how to improve fertilizer targeting (i.e., applying fertilizer at the right plant growth stage and in the right manner). This can achieve better results, especially when the crop is well weeded (Dimes et al., 2004). Recent field work in Malawi and Zimbabwe was complemented with simulation analysis to examine the trade-offs between $\mathrm{N}$ and weeding investments, taking seasonal variations into account. Results showed that a single weeding could provide roughly the same grain returns as a bag of ammonium nitrate. However, the actual return is highly variable depending on a range of factors, including rainfall, soil fertility, weed pressure and overall farm management (Fig. 6).

Recent efforts to improve fertilizer use are beginning to show results, because of the innovative approaches used. For example, ICRISAT scientists and their partners in Zimbabwe and Malawi combine crop simulation modeling with farmer-participatory research to understand and compare various technology options for fertility management, under the resource constraints that most farmers face. We are all aware that small-scale farmers simply cannot afford large inputs, especially in a drought-prone area where farming risk is high. Therefore we look for ways 


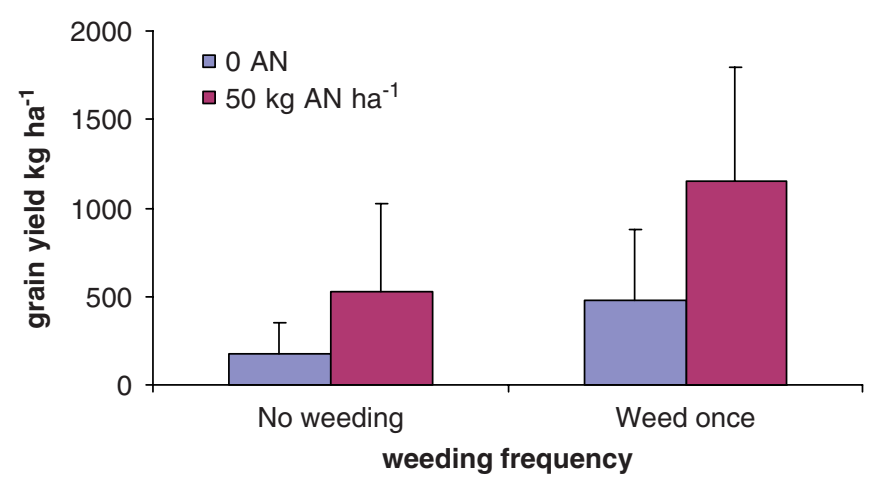

Fig. 7. Simulated maize grain yield response to weeding frequency (no weeding, and weed once 4 weeks after emergence) and two levels of ammonium nitrate $\left(0\right.$ and $\left.50 \mathrm{kgha}^{-1}\right)$ for a shallow sandy soil in Masvingo, Zimbabwe. Data show mean and standard deviation for $47 \mathrm{yr}$ of simulated yields (adapted from Dimes et al., 2004).

to maximize returns and minimize risk from a small investment - perhaps a single bag of ammonium nitrate, which is all the farmer can afford (Fig. 7).

Whilst ICRISAT focuses its efforts on resolving production problems in the semi-arid tropics, sister CGIAR Centers work within other agro-ecosystems and frequently share lessons and experiences. One example is the work of the International Center for Tropical Agriculture (CIAT), which has taken the lead in the development of participatory research approaches and decision support tools (Zapata and Ashby, 2003). Initial work was carried out in southern America where stakeholder analyses and problem prioritization highlighted the lack of decision support tools for use by local, regional and national actors in natural resource management decision making. Once such tools were developed for South America, CIAT staff began working with East African institutions to adapt and produce new approaches for Africa, that include a strong emphasis on market linkages.

\section{Priorities for the future}

Coming back to the broader questions of sustainable resource management in Africa, even intensive use of land or water does not necessarily lead to degradation. But unplanned use, where conservation has not been integrated into the system, and appropriate institutions do not exist, can rapidly destroy the natural resource base (Bennet, 2000; Mazzucato and Niemeijer, 2000; Greenland et al., 1998).

To improve crop production in marginal rainfall regions, we must develop cultural practices that conserve fragile soils (or at least prevent irreversible damage to soil structure and characteristics) and extend the period of water availability to the crop. Governments, nongovernmental organizations and others have tried to develop improved tillage/soil management systems. Unfortunately, many of the outputs, although technically sound, failed to perform under farmers' circumstances. They were developed and tested in researcher-managed trials, with only limited consideration to the problems and priorities of smallholder farmers for whom they were intended (Anderson, 1992; Ryan and Spencer, 2001).

When we talk of INRM technologies, various questions arise. The first is - are technologies available? If they are, why are they not being adopted? Is it because the technologies themselves are at fault-perhaps they are effective only under carefully managed conditions at research stations, not under a highly variable farming environment. Perhaps they are too expensive, or not cost effective. But if effective, appropriate technologies are available, is adoption being limited by lack of institutions, or by other cultural or economic factors? Are farmers simply not aware of, or not convinced by, the new technologies? On the other hand, if technologies are yet to be developed, how should we revise our research agenda? How do we make it easier for researchers to develop the right technologies, and extension agents to promote these technologies to farmers?

These are very broad questions, and hard to answer, but they should be the goal of every research scientist working in IGNRM (Campbell and Sayer, 2003).

\section{Will farmers invest?}

To date a great deal of agricultural development work in Africa (and Asia) has focused at the plot and farm level. It now needs to be extrapolated to broader regions and more sites in an attempt to answer one key research question: Under what conditions will rural households be encouraged to reinvest in their agroecosystems? This question in turn involves a host of other questions. Ultimately, we must find ways to encourage farmers to invest in their land. In many cases they have good reasons for not making such investments: the returns may not be good enough, or may come only many years later. Under such circumstances, it would be logical for them to invest time, labor and money in other areas, which give better or more immediate financial returns.

ICRISAT's studies have identified several key challenges that must be addressed if we are to get broad scale adoption by smallholder farmers. Studies by other institutes have also independently reached similar conclusions for other agro-ecosystems in Africa, so we are all generally agreed on the key challenges facing us. These are:

- Lack of a market-oriented smallholder production system where research is market led, demand driven and follows the commodity chain approach;

- Poor research-extension-farmer linkages, strengthening of which would improve the transfer and adoption of technology;

- Need for policies and strategies on soil, water and biodiversity, to offset the high rate of natural resource degradation; 
- Need to focus research on soil fertility improvement, soil and water management, development of irrigation, promotion of integrated livestock-wildlife-crop systems, and development of drought mitigation strategies;

- Need to strengthen capacities of institutions and farmers' organizations to support agricultural production systems;

- Poor information flow, lack of communication on rural development issues; and

- Need to integrate a gender perspective in agricultural research and training.

To summarize what has been said so far: we have seen the nature of the problem, and the challenges that we face. We know what we have to do. And fortunately, we can draw strength from previous research. There is a large body of work that has been developed, tested, and adopted, and has provided quantifiable benefits in many countries, including Australia, Argentina, Brazil, Chile, Canada, and USA. Unfortunately much of this work has not reached sub-Saharan Africa, for various reasons, both scientific and institutional (Twomlow and Lilja, 2004; Agricultural Systems vol. 78).

But as we share knowledge amongst ourselves, discuss case studies and learn from the failures and the successes, we are beginning to address many of the problems faced by the African smallholder farmer. Unfortunately, the major obstacle to be overcome in the intensification of smallholder agriculture, and widespread technology adoption, is the protective institutional framework that abounds throughout Africa, stifling farmer creativity and innovation.

\section{References}

Anderson, J.R., 1992. Difficulties in African agricultural systems enhancement? Ten hypotheses. Agric. Syst. 38, 387-409.

Barbier, E.B., 1998. The economic determinants of land degradation in developing countries. In: Greenland, D.J., Gregorgy, P.J., Nye, P.H. (Eds.), Land resources: on the edge of the Malthusian precipice. In: Philosophical Transactions. Royal Society and CAB International, UK pp. 31-39.

Barrett, C.B., Place, F., Aboud, A.A. (Eds.), 2002. Natural Resources Management in African Agriculture: Understanding and Improving Current Practices. CABI Publishing in Association with the International Centre for Research in Agroforestry p. 335.

Barrow, C.J., 1988. The present position and future development of rainfed agriculture in the tropics. Outlook Agric. 17 (3), 112-119.

Bennet, A.J., 2000. Environmental consequences of increasing production: some current perspectives. Agric. Ecosyst. Environ. 82, 89-95.

Benson, T., 2004. Africa's food and nutrition security situation-where are we and how did we get here? Background paper prepared for the 2020 Africa Conference on Assuring Food and Nutrition Security in Africa by 2020: Prioritising Actions, Strengthening Actors and Facilitating Partnerships, Kampala, Uganda, April 1-3, 2004. p. 63.

Campbell, B.M., Sayer, J.A. (Eds.), 2003. Integrated Natural Resource Management: Linking Productivity, the Environment and Development. CABI publishing UK in Association with Center for International Forestry Research (CIFOR), UK p. 315.
Chauhan, Y.S., Silim, S.N., Kumar Rao, J.V.D.K., Johansen, C., 1997. A pot technique to screen pigeonpea cultivars for resistance to waterlogging. J. Agron. Crop Sci. 178, 179-183.

CIMMYT, SPIA, 2003. Why has impact assessment research not made more of a difference? In: Summary Proceedings of an International Conference on Impact of Agricultural Research and Development, 4-7 February 2002, San José, Costa Rica, and organized by the CGIAR's Standing Panel on Impact Assessment (SPIA) of the Interim Science Council and Economics Program of the International Maize and Wheat Improvement Centre (CIMMYT), Mexico.

Cogle, A.L., Rao, K.P.C., Yule, D.F., George, P.J., Srinivasan, S.T., Smith, G.D., Jangawad, L., 1997. Soil management options for Alfisols in the semi-arid tropics: annual and perennial crop production. Soil Tillage Res. 44, 235-253.

Dimes, J., Muza, L., Malunga, G., Snapp, S., 2004. Trade-offs between investments in nitrogen and weeding: on-farm experimentation and simulation analysis in Malawi and Zimbabwe. In: Friesen, D.K., Palmer, A.F.E. (Eds.), Integrated Approaches to Higher Maize Productivity in the New Millennium: Proceedings of the Seventh Eastern and Southern Africa Regional Maize Conference, 5-11 February, 2002, Nairobi, Kenya, International Maize and Wheat Improvement Center (CIMMYT) and Kenya Agricultural Research Institute (KARI)

Dimes, J., Twomlow, S., Rusike, J., Gerard, B., Tabo, R., Freeman, A., Keatinge, D., 2003. Increasing research impacts through low-cost soil fertility management options for Africa's drought-prone areas. Key note paper presented at the International Symposium for Sustainable Dry Land Agriculture Systems, ICRISAT-Niamey, Niger, December, 2003.

Douthwaite, B., Delve, R., Ekboir, J., Twomlow, S.J., 2003. Contending with complexity: the role of evaluation in implementing sustainable natural resource management. Int. J. Agric. Sustainability 1, 51-68.

FAO, 1996. The State of Food and Agriculture. FAO Agriculutral Series No. 29. Food and Agriculture Organisation, Rome.

FAO, 1999. FAOSTAT 98 CD-ROM. Food and Agriculture Organisation, United Nations Statistical Databases, Rome.

Fischer, G., Heilig, G.K., 1998. Population momentum and the demand on land and water resources. In: Greenland, D.J., Gregorgy, P.J., Nye, P.H. (Eds.), Land Resources: On the Edge of the Malthusian Precipice. In: Philosophical Transactions. Royal Society and CAB International pp. $9-27$.

Freeman, H.A., Rohrbach, D.D., Ackello-Ogutu, C. (Eds.), 2002. Targeting agricultural research for the development of the semi-arid tropics of sub-Saharan Africa. Proceedings of a Workshop, 1-3 July 2002, Nairobi, Kenya, P.O. Box 39063, International Crops Research Institute for the Semi-Arid Tropics, Nairobi, Kenya, p. 372. Order Code CPE 145.

Greenland, D.J., Gregorgy, P.J., Nye, P.H. (Eds.), 1998. Land Resources: On the Edge of the Malthusian Precipice. In: Philosophical Transactions. Royal Society and CAB International p. 180.

Gregory, P.J., Ingram, J.S.I., 2000. Global change and food and forest production: future scientific challenges. Agric. Ecosyst. Environ. 82, $3-14$.

Harwood, R.R., Kassam, A.H. (Eds.), 2003. Research towards Integrated Natural Resources Management: Examples of Research Problems, Approaches and Partnerships in Action in the CGIAR. Interim Science Council, Consultative Group on International Agricultural Research, Washington, DC, USA p. 168.

Heinrich, G.M., 2004. The SADC/ICRISAT sorghum and millet improvement program: an over view. In: Heinrich, G.M. (Ed.), A Foundation for the Future: The Sorghum and Millet Improvement Program (SMIP) in Southern Africa. Proceedings of the SMIP Final Review and Reporting Workshop, 25-26 November 2003, Bulawyo, Zimbabwe, P.O. Box 776, Bulawayo, Zimbabwe, pp. 9-15.

Hess, D.E., Obilana, A.B., Grard, P., 1996. Striga research at ICRISAT. In: Moreno, M.T., Cubero, J.I., Berner, D., Joel, D., Musselman, L.J., Parker, C. (Eds.), Advances in Parasitic Plants Research. Dirección General de Investigacion Agraria, Sevilla pp. 828-834. 
Johnson, M., Temu, A., Hazell, P., 2003. Global environment for African agriculture. Conference Paper No. 17 presented at the InWent, IFPRI, NEPAD, CTA Conference on Successes in African Agriculture, Pretoria, December 1-3, p. 15.

Mazzucato, M., Niemeijer, D., 2000. Rethinking soil and water conservation in a changing society: a case study from Burkina Faso. Tropical Resource Management Papers 32. Wageningnen University and Research Centre, The Netherlands, p. 378.

Minja, E.M., Shanower, T.G., Songa, J.M., Ong'aro, J.M., Kawonga, W.T., Mviha, P., Myaka, F.A., Slumpa, S., Okurut-Akol, H., 1999. Studies of pigeonpea insect pests and their management in Kenya, Malwi, Tanzania, and Uganda. Afr. Crop Sci. J. 7, 59-69.

Nakano, H., Adu-Gyamfi, J.J., Nakamura, T., 2002. Genetic adaptation of crop plants to low nutrient environments: morphological and ecophysiological characteristics of adaptation. In: Adu-Gyamfi, J.J. (Ed.), Food Security in Nutrient Stressed Environments: Exploiting Plants Genetic Capabilities. In: Developments in Plant and Soils Sciences, vol. 95. Kluwer Academic Publishers p. 388.

NEPAD, 2002. New Partnerships for Africa's Devevlopment. Comprehensive Africa Agriculture Development Programme (CAADP). Prepared with collaboration of the Food and Agriculture Organization of the United Nations, p. 140.

Perez, C., Tschinkel, H., 2003. Improving watershed management in developing countries: a framework for prioritizing sites and practices. AgREN Network Paper No. 129, July 2003. ODI, London, 15pp.

Pound, B., Snapp, S., McDougall, C., Braun, A. (Eds.), 2003. Managing Natural Resources for Sustainable Livelihoods: Uniting Science and Participation, IDRC and Earthscan Books, London, UK.

Reij, C., Scoones, I., Toulmin, C. (Eds.), 1996. Sustaining the Soil. Indigenous Soil and Water Conservation in Africa. Earthscan, London, UK.

Rusike, J., Snapp, S., Twomlow, S.J., 2005. Mother-baby trial approach for developing soil, water and fertility and management technologies. In: Becker, J.T., Braun, A., Campilan, D., De Cnavez, H., Fajber, E., Kapiriri, M., Rivaco-Caminade, J., Vernooy, R. (Eds.), Participatory research and development for sustainable agriculture and natural resource management: A sourcebook. Chapter 68 Volume 3: Doing participatory research and development. International Potato CenterUsers' Perspectives with agricultural research and development, Laguna, Philippines and International Development Research Centre, Ottawa, Canada. 102-109.

Ryan, J.G., Spencer, D.C., 2001. Future challenges and opportunities for agricultural $R \& D$ in the semi-arid tropics. International Crops Research Institute for the Semi-Arid Tropics, Patancheru, AP 502 324, India, p. 83, Order code IBE 062.
Sanchez, P.A., 2002. Soil fertility and hunger in Africa. Science 295, 2019-2020.

Shiferaw, B., Freeman, H.A. (Eds.), 2003. Methods for assessing the impacts of natural resource management research. A summary of the Proceedings of the International Workshop, 6-7 December 2002, International Crops Research Institute for the Semi-Arid Tropics (ICRISAT), Patancheru 502 324, India. Order code CPE148.

Snapp, S.S., Mafongoya, P., Waddington, S., 1998. Organic matter technologies or integrated nutrient management in smallholder cropping systems of southern Africa. Agric. Ecosyst. Environ. 71, 185-200.

Twomlow, S.J., Lilja, N., 2004. The role of evaluation in successful integrated natural resource management. Invited paper, Symposium 5 on Research Planning, Monitoring and Evaluation to Improve Impact, Theme 4 on Crop Science for Effecting Change at the Fourth International Crop Science Congress, Brisbane Convention and Exhibition Centre in Queensland, Australia, 26 September-1 October 2004, p. 10.

Twomlow, S.J., Rusike, J., Snapp, S.S., 2004. Biophysical or economic performance which reflects farmer choice of legume Best Bets in Malawi. In: Friesen, D.K., Palmer, A.F.E. (Eds.), Integrated Approaches to Higher Maize Productivity in the New Millennium, Proceedings of the Seventh Eastern and Southern Africa Regional Maize Conference, 5-11 February 2002, Nairobi, Kenya, International Maize and Wheat Improvement Center (CIMMYT) and Kenya Agricultural Research Institute (KARI), pp. 480-486.

USDA, 2000. Factbook. USDA, Washington, DC, 〈www.usda.gov〉.

Wani, S.P., Singh, H.P., Sreedevi, T.K., Pathak, P., Rego, T.J., Shiferaw, B., Iyer, S.R., 2003. Case 7: Farmer-participatory integrated watershed management: Adarsha Watershed, Kothapally India. An innovative and upscalable approach. In: Harwood, R.R., Kassam, A.H. (Eds.), Research Towards Integrated Natural Resources Management: Examples of Research Problems, Approaches and Partnerships in Action in the CGIAR. Interim Science Council, Consultative Group on International Agricultural Research, Washington, DC, USA pp. 123-148.

Zapata, V., Ashby, J., 2003. Case 2: Dissemination and application of decision support tool (DST) for natural resource management. In: Harwood, R.R., Kassam, A.H. (Eds.), Research Towards Integrated Natural Resources Management: Examples of Research Problems, Approaches and Partnerships in Action in the CGIAR. Interim Science Council, Consultative Group on International Agricultural Research, Washington, DC, USA pp. 47-64. 